Pobrane z czasopisma Annales N - Educatio Nova http://educatio.annales.umcs.pl Data: 26/04/2023 12:37:43

W Y D A W I C T W O U M C S

\begin{tabular}{lc}
\hline & ANNALES \\
& UNIVERSITATIS MARIAE CURIE-SKŁODOWSKA \\
VOL. VI & LUBLIN - POLONIA \\
\hline
\end{tabular}

ISSN: 2451-0491 • e-ISSN: 2543-9340 • CC-BY 4.0 • DOI: 10.17951/en.2021.6.359-376

\title{
Diagnostics of the Parameters of the Syllaborhythmic Speech Structure in Pre-School Children with Complex Disoders
}

\section{Diagnostyka parametrów sylaborytmicznej struktury mowy u dzieci przedszkolnych z zaburzeniami kompleksowymi}

\author{
Nataliia Babych \\ Borys Grinchenko Kyiv University \\ Institute of Human Sciences \\ 18/2 Bulvarno-Kudriavska Str., Kyiv, Ukraine, 04053 \\ natalia.logoped@gmail.com \\ https://orcid.org/0000-0001-8923-8960 \\ Kateryna Tychyna \\ Borys Grinchenko Kyiv University \\ Institute of Human Sciences \\ 18/2 Bulvarno-Kudriavska Str., Kyiv, Ukraine, 04053 \\ kate.kibi@gmail.com \\ https://orcid.org/0000-0002-3072-0450
}

\begin{abstract}
Abstrakt. Rozwój mowy dzieci to jeden z głównych czynników kształtowania osobowości, determinujący ich umiejętności społeczne i poznawcze. Zaburzenia rozwoju mowy (w szczególności przyswajanie przez dzieci konstrukcji syntagmatycznych o różnej złożoności strukturalnej) utrudniają im komunikowanie się zarówno z rówieśnikami, jak i z dorosłymi, a także kształtowanie umiejętności
\end{abstract}


pisania. Celem niniejszego opracowania jest przeanalizowanie podstawowych parametrów sylaborytmicznej struktury mowy (ruch, rytm, przestrzeń) oraz określenie poziomu jej rozwoju u dzieci w wieku przedszkolnym z zaburzeniami kompleksowymi (czucia, ruchu, mowy). W celu zbadania tych parametrów opracowano specjalną metodę składającą się z czterech jednostek diagnostycznych (ruch rytmiczny, przestrzeń rytmiczna, wymowa rytmiczna, złożony rytm mowy). W pierwszej kolejności przeprowadzono badanie empiryczne dla każdej jednostki diagnostycznej. Na podstawie uzyskanych wyników należy stwierdzić, że większość dzieci w wieku przedszkolnym z zaburzeniami czucia, motoryki i mowy ma niesformowaną sylaborytmiczną strukturę mowy, co wymaga dalszych ukierunkowanych działań. Badanie wykazało, że dzieci w wieku przedszkolnym z zaburzeniami kompleksowymi mają obniżoną zdolność wymawiania słów o różnej złożoności strukturalnej, zaburzoną percepcję jednostek leksykalnych oraz zaburzoną zdolność wykonywania dynamicznych i rytmicznych ruchów szeregowych, co świadczy o niewystarczającym poziomie umiejętności motorycznych, rytmicznych i przestrzennych. Następnie przeprowadzono analizę korelacyjną, której wyniki wskazują, że trzy jednostki diagnostyczne: ruch rytmiczny, przestrzeń rytmiczna oraz wymowa rytmiczna - są ze sobą nierozerwalnie związane. Gdy zostaną ukształtowane, dopiero wówczas zacznie się formować jednostka określona jako złożony rytm mowy. Określenie poziomu funkcjonowania dziecka w każdej jednostce diagnostycznej pozwala na ustalenie skutecznych strategii oddziaływania na parametry sylaborytmicznej struktury mowy dzieci z zaburzeniami kompleksowymi w oparciu o potencjalne możliwości i ich maksymalne wykorzystanie w trakcie pracy logopedycznej.

Słowa kluczowe: sylaborytmiczna struktura mowy; konstrukcje syntagmatyczne; rytm mowy; dzieci przedszkolne z zaburzeniami kompleksowymi; zaburzenia rozwoju mowy

\begin{abstract}
A child's language development is one of the main factors of the personal formation. The level of personal development determines the formation of social and cognitive skills in children. Speech development disorders, in particular mastering of syntagmatic constructions with different structural complexity, complicates children's communication with peers and adults and impedes written language development. The purpose of this study is to examine the basic parameters of the compositional rhythmic speech structure (movement, rhythm and space) and to determine its development level in preschool children with multiple disabilities (disabilities in sensory, motor and speech systems). In order to examine these parameters a special technique consisting of four diagnostic units ("rhythmic movement", "rhythmic space", "rhythmic pronunciation" and "complex rhythm of speech") was developed. First, an empirical study for each diagnostic unit was conducted, and the findings suggested that majority of preschool children with sensory, motor and speech disorders have underveloped compositional structure of speech, which requires further targeted interventions. The study found that preschool children with multiple disabilities have a reduced ability to pronounce words with different structural complexity, impaired perception of lexical units and a disturbed ability to perform dynamic and rhythmic serial movements, which indicates an insufficient level of motor, rhythmic and spatial skills development. Then, a correlation analysis was performed, the results of which indicate that the diagnostic units - "rhythmic movement", "rhythmic space", "rhythmic pronunciation" - are inextricably linked. When the skills assessed by the above-mentioned diagnostic units are developed, the skills, assessed by the "Complex rhythm of speech" diagnostic unit can begin their development as well. Determination of the child's functioning level in each diagnostic unit will allow describing the effective strategies to influence parameters of compositional rhythmic speech in children with multiple disabilities based on potential capabilities and their maximal implementation in the speech therapy process.
\end{abstract}

Keywords: syllaborhythmic speech structure; syntagmatic constructions; rhythm of speech; pre-school children with complex disoders; speech development disorders 


\section{INTRODUCTION}

The priority of the modern system of special education is to create appropriate conditions for the development and self-realization of each child. In recent decades, a recognition has emerged that a child's full-fledged communication with the social environment is not only a key factor in mental and social development but also a factor in preventing and overcoming possible difficulties in personal development. Certainly, the full-fledged communication for a child is impossible without an adequate level of speech development, the formation of which takes place at preschool age.

The study of speech activity in neurotypical children and children with disabilities is a field of research for many scientists around the world. Thus, based on the levels of movement construction theory, N. Bernstein considered speech as a complex social function. This theory is based on the idea that five levels of the brain (A, B, C, D and E) are involved in the control of any type of human activity. The more complex the activity, the more levels are involved in the control over this activity. According to Bernstein's theory, speech is implemented only at the last two levels. At the same time, the first three levels A, B and C are inherent in both animals and humans, and are the basis for higher levels. Simultaneously, in order for speech to be formed, the basic parameters provided by the work of A, B and C levels must function properly (Bernshtein 1947). By basic parameters, we understand "movement" (levels A and B), "rhythm" (level B) and "space" (levels A, B and C).

According to A. Tierney, T. White-Schwoch, J. MacLean and N. Kraus, understanding of individual differences in rhythmic skills may help to explain the variability of language skills as a whole. Scientists have studied the neural basis of rhythm and its effect on language skills in young people. They characterize rhythmic abilities by two constructs that are connected to independent language skills and neural profiles: rhythm sequencing and synchronization. Rhythm sequencing ability is associated with verbal memory, and the ability to synchronize is linked only to auditory processing of non-verbal information. Researchers have shown that the perception of rhythm in different time scales reflects clear abilities that rely on individual aural and neural resources, while proper rhythmic processing has a positive effect on language skills (Tierney et al. 2017).

According to D. Poeppel and M.F. Assaneo, speech recognition is usually studied by focusing on either words or their elements (syllables or phonemes), as is the case in our study. Many recent researches are focused on audio-motor interactions in speech, highlighting behavioral and neural evidence that demonstrates how properties of perceptual and motor systems as well as their relation, 
may underlie mesoscale speech rhythms. The study by Poeppel and Assaneo proposes the hypothesis that the speech cortex is best modeled as a neural generator, which emphasizes the fundamental role of nerve oscillations in the perception and recognition of speech. The important thing is that this rhythmicity is required by the processes underlying the decoding of the constituent elements of speech for their proper reproduction (Poeppel and Assaneo 2020).

The research of M.S. Benninger, E.S. Zhang, B.N. Chen, W.S. Tierney, B. Abdelmalak and P.C. Bryson is also closely related to our statement about the connection between rhythm and speech. Scientists note that awareness of speech flow requires segmentation of the acoustic flow into discrete linguistic elements (decoding and coding of syllables). Speech comprehension also depends heavily on contextual cues that help to predict the structure and content of speech. The authors present a model for distinguishing and recognizing syllables in natural speech flow that combine predictive coding and neural oscillations. This model shows that the concepts of predictive coding and neural oscillations can be combined to account for the dynamic processing of sensory information (Benninger et al. 2021).

Relevant scientific publications (Freina and Ott 2014) deal with spatial perception, mobility and orientation. They use the concept of spatial intelligence, which refers to a set of competencies involving the space perception and space self-perception. It is a part of the basic practical skills that form a basis for various cognitive tasks, and it is a prerequisite for autonomous mobility, which is important for children with disabilities, in particular speech disabilities.

The study of N.S. Newcombe and A. Frick on spatial concepts and thinking is of the same interest. According to those researchers, they have evolutionary significance for any organism. Abilities for mental and spatial transformation in infants, young children and preschool children are considerably developed and show individual distinctions. The researchers emphasize that the promotion of spatial thinking in preschool children has a positive impact on speech development and more (Newcombe and Frick 2010).

According to S. Greenberg, H. Carvey, L. Hitchcock and S.Y. Chang, the ability to understand speech depends on the wide distribution of syllable duration in each language, which is reflected in the modulation spectrum of the acoustic signal. If the child does not use the emphasis correctly, speech intelligibility is reduced. Statistical analysis in this study shows that most of the temporal changes observed at the level of component and phonetic segments can be taken into account by two main parameters: (1) stress-accent pattern and (2) position of the segment within the syllable (Greenberg et al. 2003). We note that in the Ukrainian language, the emphasis is also important and it is variable, which ensures the melody of speech. 
Theoretical research on the outlined issues (Efimova 2007; Vizel 2005) points out that timely mastering of speech is associated with the development of motor, rhythmic and spatial reactions. After all, speech is a motor act performed in space and is characterized by rhythmic movements of the articulatory organs to produce phrases. The aforementioned is a prerequisite for mastering the compositional rhythmic structure of speech ("Complex rhythm of speech"). The compositional rhythmic structure of speech is a rhythmic alternation of syntagmatic constructions of different structural complexity in the speech flow, which is provided by prosodic components of speech.

Based on the theoretical understanding of the "compositional rhythmic speech structure" concept we emphasize that the syllabic structure is a genetically new formation of speech. The formation of the "sound content of the word's syllabic contour" is associated with rhythmic-intonational phonological means of speech, which arise directly from the pre-speech components of communication (Babych and Tychyna 2019). Thus, examining the parameters of the compositional rhythmic speech structure in order to establish the peculiarities of their development in preschool children with multiple disabilities as well as in neurotypical children is a relevant issue.

The study of the outlined parameters of the compositional rhythmic structure of speech in preschool children at the present stage of science development is an extremely important task as it allows predicting speech activity difficulties among children and identifying the ways to overcome them.

In the psychological and pedagogical literature, there are many approaches to the assessment of compositional rhythmic structure. In most scientific works, the focus is on the children's ability to divide words into syllables, following a certain order, which depends on the so-called difficulties of syllable division, the number of syllables in the word, their sound content, etc. (Bolshakova 2017; Chetverushkina 2016; Markova 1961; etc.). Another group of scientists focuses on the fact that the strength of unstressed syllables in a word is different. The child reproduces the syllabic structure of a word focusing on the strength of its pronunciation: the first stressed syllable, then - the first unstressed syllable, and at last - weak unstressed syllables. If a child misses weak unstressed syllables, it leads to the omission of sounds, which is the cause of speech disorders (Cherednichenko 2016; Shvachkin 2004; Tkachenko 2004; etc.). Studies of the word's compositional structure are presented in the works of specialists from various scientific fields (Agranovich 2001; Babina and Sharipova 2020; Filicheva and Chirkina 1993; Levina 2005; etc.).

Therefore, the specialized literature presents theoretical and practical experience of assessment and influence on the compound word formation in children 
with various speech disorders. However, the lack of theoretical information on the peculiarities of compositional rhythmic structure of speech mastering by children with multiple disabilities and its impact on the perception and understanding of oral text, prompted us to create the method of its systematic study as a prerequisite for effective speech development.

The aim of this study is to examine the basic parameters of the compositional rhythmic structure of speech (movement, rhythm and space) and determine the state of its development in preschool children with multiple (sensory, motor and speech) disabilities.

\section{METHODS}

\section{Participants}

The study involved 100 children who are currently attending mainstream kindergartens and are competent in Ukrainian. The sample consisted of five groups of children among which there were 20 children with a speech impairment, 20 children with a visual and speech impairment, 20 children with a hearing and speech impairment, 20 children with a musculoskeletal and speech impairment and 20 neurotypical children. The average age of children was $4-5$ years. For the normative sample, children of nine preschool educational institutions No. 9, 49, 95, 323, 577, 582, 485, 590, 591 in Kyiv were invited to participate. It is important to note that all tested children had age-appropriate level of intelligence.

\section{Design}

To achieve the research goal, namely to study the main parameters of the compositional rhythmic structure (movement, rhythm, space) within the identification of its development level in children with sensory, motor and speech disorders, a specially developed pedagogical diagnostics method was used. Field work has been conducted from October 2017 to May 2019.

The method of studying the compositional structure of speech consisted of four diagnostic units ("Rhythmic movement", "Rhythmic space", "Rhythmic pronunciation" and "Complex rhythm of speech"). Each unit had a series of tasks aimed at assessing a different parameter.

The first diagnostic unit ("Rhythmic movement") consisted of a set of tasks aimed at determining the level of development of simple and complex motor acts, serially organized body motor actions, coordination of complex serial parameters of movements and actions, both in dynamic and rhythmic aspects. 
For example, performing a series of movements with the hands / legs / organs of the articulatory apparatus in a given rhythm with and without emphasis.

The second diagnostic unit ("Rhythmic space") consisted of a set of tasks aimed at determining the features of the spatial organization of body movements within different planes of preschool child visuospatial orientation and mobility. For example, performing a series of movements with the hands / legs / organs of the articulatory apparatus with a change of direction in space in accordance with the teacher's instructions.

The third diagnostic unit ("Rhythmic pronunciation") consisted of a set of tasks aimed at determining the characteristics of perception and reproduction of syllables and words of different structural complexity as well as determining the presence or absence of accentuated components in the composite series. For example, differentiation of syllables and words that have a different number of structural elements (with and without visual support).

The last, fourth diagnostic unit ("Complex rhythm of speech") consisted of a set of tasks that allowed to determine the features of perception and reproduction of syntagmatic constructions of different structural complexity (words, phrases and sentences that have intonation-semantic unity) as well as the use of prosodic components of speech. For example, performing a rhythmic program of movements in the process of pronouncing syntagmatic structures of various structural complexity.

The method of studying the compositional rhythmic structure was adapted for children with different levels of functioning. Particular attention was paid to the selection of available material and equipment to perform diagnostic tasks. Preference was given to diagnostic tools that helped to stimulate, and to suggest the content and methods of performing the diagnostic task. Different ways of children activation were used: 1 ) a teacher is the initiator, suggests and at the same time demonstrates his/her own interest or creates search conditions; 2) a teacher is connected to the task child performs or refuses to complete.

In the process of the material selection, a number of important factors were taken into account, namely respecting the individual capabilities of each child; compliance of the material with the content of the task for different age categories as well as the structure of disabilities in children with multiple disabilities; realism of the objects and their images; availability of material for perception by each child; diagnostic expediency of the material use; external attractiveness and aesthetics; adaptation of the selected material to the features of impaired functions in preschool children with multiple disabilities.

If a child did not cope with the tasks (did not understand the content of the question, did not know the answer or could not answer for other reasons, etc.) 
it was difficult to determine its current level of development. To deal with this, certain means were used, among them there were additional, auxiliary guiding questions and tips. Children were encouraged to use non-verbal means to express their thoughts, which allowed revealing their experience and determining the zone of the potential development, which was not actualized verbally due to the immaturity of verbal ideas and the lack of expressive vocabulary.

Considering the peculiarities of educational and playing activities of preschool children with multiple disabilities, increased fatigue they have, during various types of diagnostic activities, the following time concepts were used: an individual session lasted 10-15 minutes per day, a group diagnosis - 10 minutes per day. The results were daily analyzed and recorded in appropriate protocol forms and summary tables.

Furthermore, statistical processing and generalization of the obtained empirical data took place, and the indicators identified for each individual side were combined into a general level of formation of the compositional rhythmic structure of speech.

The following reference criteria were taken for assessing the levels of formation.

The high level of formation of the compositional rhythmic speech structure in a preschool child is characterized by a high focus on faultless tasks performance. A child easily reproduces the complex motor acts parameters (rhythmic and dynamic) and successfully organizes a series of movements, has no difficulties in performing them; independently and dynamically reproduces rhythmic movements and their structure, keeps in memory the sequence of movements during the examination; somatic and spatial orientation and spatial organization of arm and leg movements are sufficiently developed; spatial concepts and orientation in two- and three-dimensional space are formed; the skill of maintaining the proposed strategy of spatially-organized activities and spatially-oriented actions in the process of visual and constructive activities is formed; the development of visuospatial orientations within the experimental time is observed at a sufficient level; the skill to perceive and evaluate the length of the word, understanding of components in the composite series accentuated by the teacher; a child's ability to identify dysrhythmias and distortions in lexical units is developed; a preschool child's basic ability to make reliable predictions and segmental analysis of the word and the ability to determine the specificity of prognostic operations on different material are formed; syllable word structure with spontaneous pronunciation and skills of using words of simple and complex component structure in the minimal context are formed; self-monitoring, self-correction, performance of diagnostic tasks without errors and additional 
hints, accuracy of reproduction of the offered consecutive movements (completeness or fragmentation of reproduction), automation, accuracy and speed of tasks performance are available.

The intermediate level of the compositional rhythmic structure of speech formation in a preschool child is characterized by a sufficient focus on unmistakable task implementation. A child reproduces the complex parameters of motor acts (rhythmic and dynamic) and organizes a series of movements, having little difficulty in performing them; dynamically reproduces rhythmic movements and their structure, difficulty in remembering the sequence of movements during the examination; somatic and spatial orientation as well as spatial organization of arm and leg movements are sufficiently developed; spatial representations and orientation in two- and three-dimensional space are formed; skills of maintaining the proposed strategy of spatially-organized activities and spatially-oriented actions in the process of visual and constructive activities are formed; the development of visuospatial orientations within the experimental time is observed at a sufficient level; the skill to perceive and evaluate the length of the word, accent components selected by a teacher in the composite series is selectively available; a child's ability to identify dysrhythmias and distortions in lexical units is insufficiently formed; a preschool child's elementary ability to make reliable predictions and segmental analysis of the word is available; component of the word structure in spontaneous pronunciation and skills of using words of simple and complex component structure in the minimal context are insufficiently formed; simple syntagmatic constructions are available for reproduction by a child, but complicated ones are reproduced with errors, corresponding prosodic components are not used or used partially; self-monitoring of errors, sometimes self-correction, are available; diagnostic tasks are performed with single errors and additional tips, partial accuracy of reproduction of the offered consecutive movements (completeness or fragmentation of reproduction), automation, partial accuracy and speed of tasks.

The entry level of formation of the compositional rhythmic structure of speech in a preschool child is characterized by the performance of tasks with errors. A child does not reproduce the complex parameters of motor acts (rhythmic and dynamic); has significant difficulties in performing serial movements; has difficulty remembering the sequence of movements during the examination; somatic and spatial orientation and spatial organization of hand and foot movements are disturbed; spatial representations and orientation in two- and three-dimensional space are partially formed or unformed; the skill of maintaining the proposed strategy of spatially-organized activities and spatially-oriented actions in the process of visual and constructive activities is 
unformed; the development of visuospatial orientation within the experimental time is impaired; a child is not able to perceive and evaluate the length of the word, the accent components selected by the teacher in the composite series; an insufficiently formed or unformed ability of a child to determine dysrhythmias and distortions in lexical units; lack of abilities in a preschool child to make reliable predictions and segmental analysis of the word; compound structure of the word in spontaneous pronunciation and skills of using words of simple and complex compound structure in a minimal context are disrupted; simple and complex syntagmatic constructions are not reproduced by a child; there is no self-control of errors, self-correction is seldom observed, the task is performed with errors and additional hints, the accuracy of reproduction of the offered consecutive movements (completeness or fragmentation of reproduction), and also automation, accuracy and tasks performance speed are broken.

\section{RESULTS AND DISCUSSION}

According to the results of the study, we can summarize the diagnostic data of the state of formation of the dynamic and rhythmic organization of serial movements on the "Rhythmic movement" diagnostic unit, which is presented in Fig. 1.

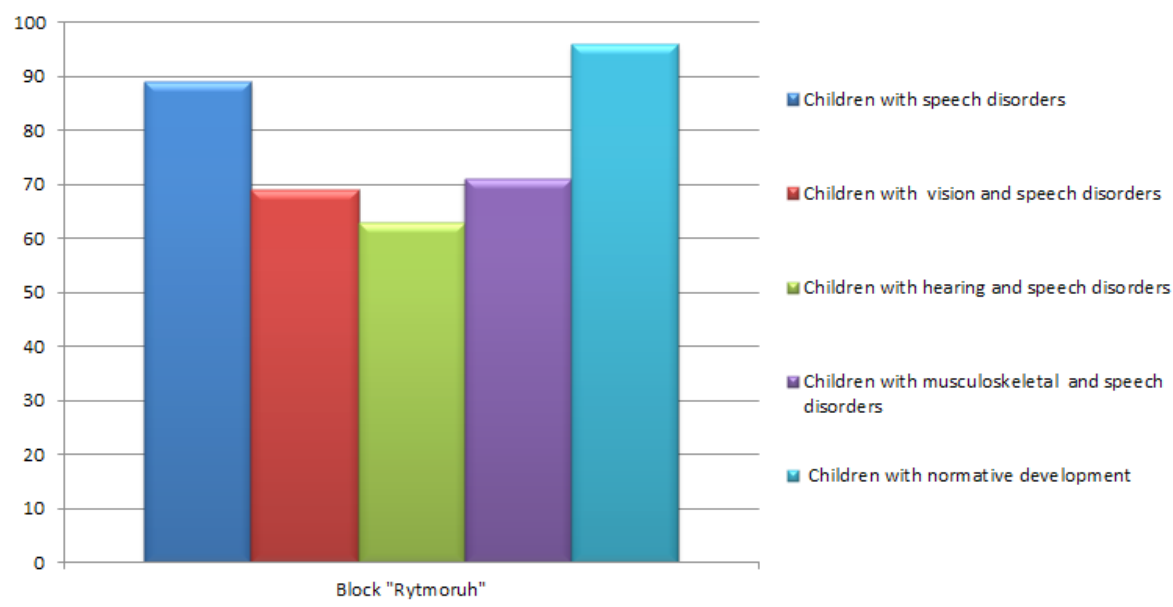

Fig. 1. Block "Rytmoruh"

Source: Authors' own elaboration. 
Let us denote the most significant results for the "Rhythmic movement" diagnostic unit. In this way, children with hearing and speech as well as vision and speech disorders have the lowest score (63\% and 69\%, respectively). This indicates that when the sensory system is impaired, it is more difficult for children to imitate and reproduce dynamic and rhythmic motor acts, which is the basis of the compositional rhythmic structure of speech. They have difficulties in performing coherent movements and actions, as well as in the reproduction of rhythmically organized series of movements of the articulatory organs, arms and legs. Violation of sensory systems reduces motor activity due to limited movement in space, considering that for active motor activity a child must actively use sight and hearing to analyze the environment for the purpose of safe movement provision. In children with disorders of the musculoskeletal system and speech, motor disorders are caused by organic lesions of the central nervous system and this is the reason for the entry level of motor acts formation (rhythmic and dynamic).

All the aforementioned provides evidence that for children with multiple disabilities it is necessary to carry out interventions focused on the "movement" parameter, which underlies compositional rhythmic speech structure. These include, developing skills such as performing simple and complex motor acts, serial organization of body motor actions, coordinating complex serial movements and actions parameters, both in dynamic and rhythmic aspects.

Analysis of the results of the formation status of visuospatial orientation as well as mobility in the "Rhythmic space" diagnostic unit in preschool children is represented in Fig. 2.

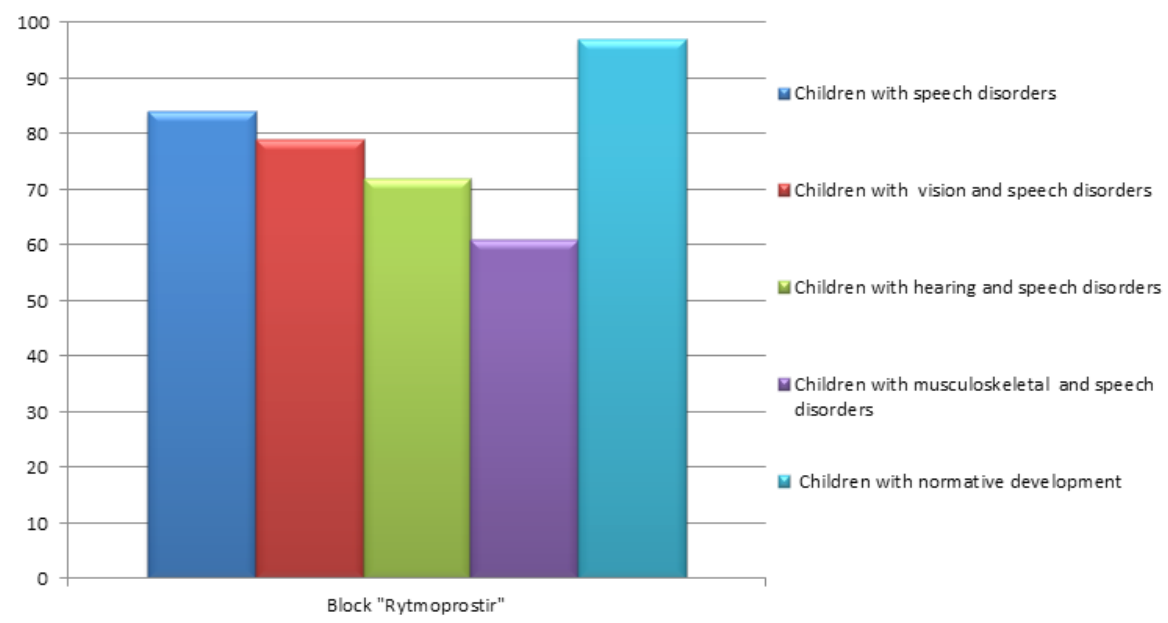

Fig. 2. Block "Rytmoprostir"

Source: Authors' own elaboration. 
Considering the study results of the "Rhythmic space" diagnostic unit, all children with multiple disabilities have specific difficulties in visuospatial orientation; however, the greatest difficulties were caused by tasks of this diagnostic unit in children with musculoskeletal and speech disorders (61\%), due to limited mobility in space and the ability to follow the spatial algorithm of actions formed at the initial level.

In children with visual and speech desorders the rate is slightly higher (72\%). However, due to the violation of the visual analyzer, it was difficult for children to navigate in their own body, relatively to themselves and from themselves, they did not use the reference frame in the main directions when orienting in the surrounding space; the use of different methods of orientation in microspace (macrospace) with the help of aids (subject landmarks, marks, etc.) was violated.

Children with hearing and speech impairments performed better (79\%). They moved confidently in a familiar space in accordance with one- and twopart instructions, they managed to follow the spatial algorithm of actions, etc. But they still had difficulty using different methods of orientation in microspace (macrospace) with the help of sounds.

Children with speech disorders met the challenge the best among children with multiple disabilities (84\%). They had the greatest difficulty in performing tasks according to verbal instructions.

It follows that the generalized results of the "Rhythmic space" diagnostic unit show a violation of another parameter of the rhythmic structure of speech, namely "space". They are characterized by disorders of spatial organization of body movements within different planes, visuospatial orientation and mobility in preschool children with disorders of sensory, motor and speech sphere in comparison with neurotypical peers. In this regard, we note that interventions for children with disorders of multiple systems requires modernization and new integrated techniques application, based not on the disorder, but on the child's current level of functioning. Such work should be aimed at forming the "space" parameter of the compositional rhythmic speech structure, namely forming child's ability to orientate in one's own body, in the objects' remoteness from oneself and their distance in space, as well as to create the simplest models of spatial relations, to use different ways of orientation in microspace (macrospace), to navigate with the help of aids, and to follow the spatial algorithm of actions, etc.

The analysis of features of component registration of syllables as well as words of various structural complexity in children of preschool age is provided in Fig. 3. 


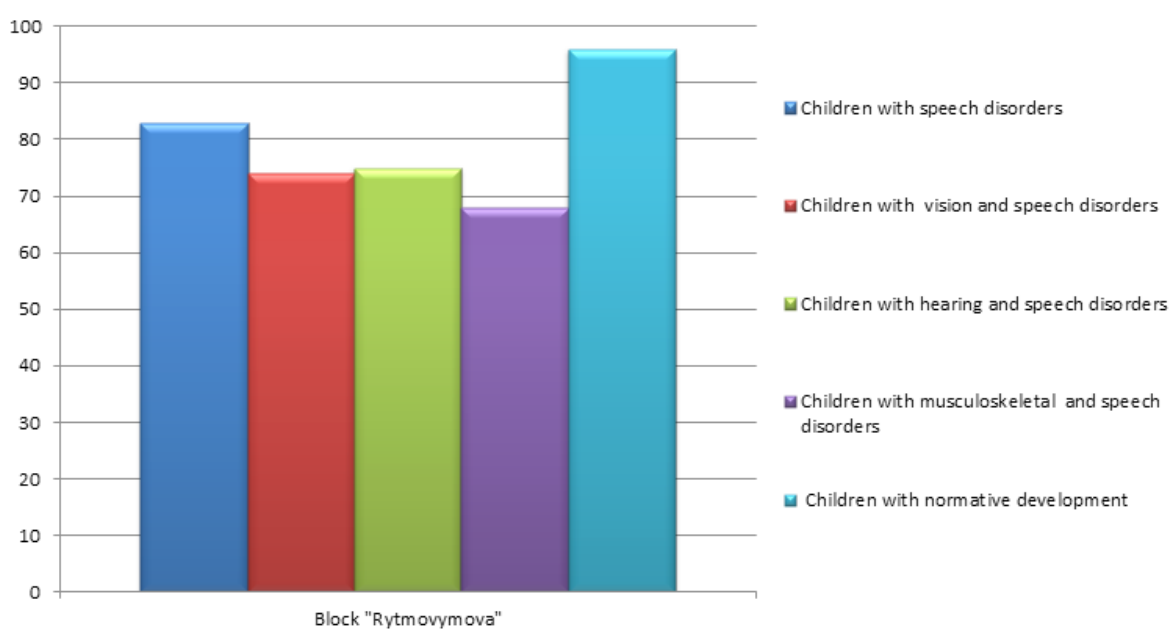

Fig. 3. Block "Rytmovymova"

Source: Authors' own elaboration.

According to the results of the study of the third diagnostic unit ("Rhythmic pronunciation"), it is determined that the ability to reproduce syllables and words of different structural complexity for children of all nosologies causes some difficulties, especially for children with musculoskeletal and speech disorders (68\%), which may be determined by the specific nature of their kinetic and kinesthetic sensitivity.

Almost the same level of formation of the constituent words design perception and reproduction of different structural complexity constructions was demonstrated by children with sensory and speech disorders. They had difficulty perceiving and evaluating the length of the word, the accent components selected by the teacher in the composite series. They have insufficiently formed or unformed skills to determine dysrhythmias and distortions in lexical units, lack of skills for reliable prediction and segmental word analysis and there is specificity of prognostic operations on different material. All of this relates to the limited perception of verbal material due to impaired visual gnosis in children with visual and speech impairments as well as auditory gnosis in the latter.

The best results were shown by preschool children with speech disorders (83\%). During the survey, the greatest difficulties for these children were caused by the task of determining the accentuation of structural elements and tasks aimed at recognizing and differentiating words that have the same fragments. This indicates the presence of an impaired speech function and problems with the verbal material perception. 
Consequently, the generalized results of the "Rhythmic pronunciation" diagnostic unit stated violations of perception and reproduction of syllables and words of different structural complexity; insufficient skills for determination of existance of accentuated components in the composite series. According to the results of our study, there is evidence to suggest that for children with different levels of functioning, it is necessary to deliver special interventions focused on the "rhythm" parameter development, which underlies the rhythmic structure of speech. This is the ability to pronounce syllables, words of different structural complexity, to synchronize the rhythm of body movements in space with the pronunciation of syllables and words of different structural complexity, as well as to determine the presence or absence of an accentuated components in the syllable and to form skills of segmental word analysis.

The analysis of the results of the state of formation of perception and reproduction of syntagmatic constructions of different structural complexity, as well as the use of prosodic components of speech is shown in Fig. 4.

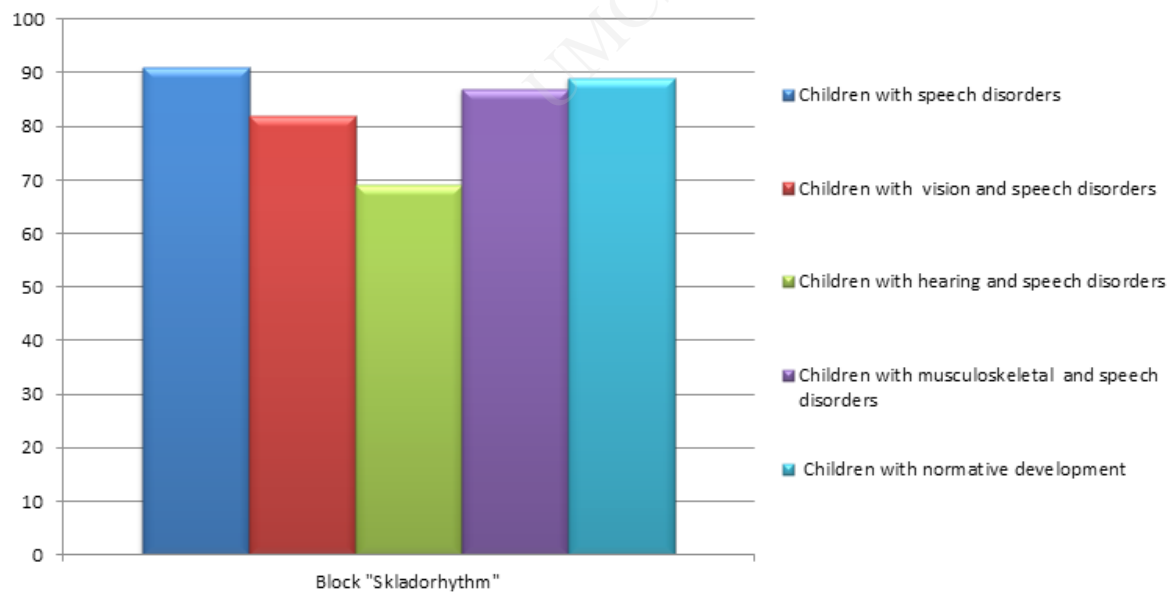

Fig. 4. Block "Skladorhythm"

Source: Authors' own elaboration.

The most interesting are the results of the "Complex rhythm of speech" diagnostic unit. Children show fairly high results compared to other units. This indicates the presence of the so-called "office" speech during group speech therapy with children. Namely, a speech therapist trains children to build sentences and simple stories according to the scheme. However, outside the speech therapy room, children are bad at production of their own statements. This is especially noticeable while at school, when children master written speech, 
which is provided by the rhythmic alternation of syntagmatic constructions of different structural complexity.

The results of Pearson's correlation analysis were especially important for our study (Table 1). Thus, significant direct relationships have been identified among all diagnostic units of the compositional structure of speech, which primarily proves the integrity and systematic nature of the diagnostic technique, as well as the possibility of its application for children of different nosologies.

Table 1 . The results of correlation analysis

\begin{tabular}{|l|l|l|l|c|}
\hline & \multicolumn{1}{|c|}{ I. Rytmoruh } & II. Rytmoprostir & III. Rytmovymova & IV. Skladorhythm \\
\hline I. Rytmoruh & 1 & - & - & - \\
\hline II. Rytmoprostir & $0.625207686^{*}$ & 1 & - & - \\
\hline III. Rytmovymova & $0.843117237^{* * * * *}$ & $0.770040077^{* * * *}$ & 1 & - \\
\hline IV. Skladorhythm & $0.689453889^{* * *}$ & $0.787264857^{* * * *}$ & $0.704000138^{* * *}$ & 1 \\
\hline
\end{tabular}

* $\mathrm{p} \leq 0.05 ;{ }^{* * *} \mathrm{p} \leq 0.01 ;{ }^{* * *} \mathrm{p} \leq 0.001$

Source: Authors' own elaboration.

The results of Pearson's correlation analysis show that the most significant (at the level of significance $\mathrm{p} \leq 0.001$ ) relationships are with such diagnostic units as "Rhythmic pronunciation" with "Rhythmic movement", $(r=0.84)$ and with "Rhythmic space" $(r=0.77)$; "Complex rhythm of speech" with "Rhythmic space" $(r=0.787)$. This indicates that the improvement of the diagnostic unit marks a positive change in "Complex rhythm of speech" and vice versa. Also, quite significant (at the level of significance $\mathrm{p} \leq 0.01$ ) relationships were found between "Rhythmic pronunciation" and "Rhythmic movement" $(r=0.689)$, as well as between "Rhythmic pronunciation" and "Rhythmic space" $(r=0.7)$. This indicates that the formation of the diagnostic unit indicators improves the performance of rhythmic pronunciation and vice versa. The work of the parameters of "Complex rhythm of speech" and "Rhythmic pronunciation" also interacts, influencing each other's dynamics. The lowest level of significance of the relationship p $\leq 0.05$ was found between the "Rhythmic space" and "Rhythmic movement" diagnostic units $(\mathrm{r}=0.625)$. This indicates that if the formation of at least one of the above-mentioned diagnostic units of the compositional rhythmic structure of speech takes place, there will be the formation process and influence on others. It was that aspect confirming our vision that the main parameters of the formation of the compositional rhythmic structure of speech are movement, rhythm and space. 


\section{CONCLUSIONS}

The system of speech development, in particular mastering of the compositional rhythmic component of speech, directly depends on its parameters development. Timely acqusition of this system in preschool age children is determined by the development of its main parameters - movement, rhythm and space, which depends on the state of formation of simple and complex motor acts, visuospatial orientation and mobility, perception of rhythmic and structural characteristics of the word, etc.

The materials of the study stated that the basic parameters of speech formation, in particular its compositional rhythmic structure, are movement, rhythm and space. When at least one parameter is impaired, an imbalance appears and all speech structures become impaired. Thus, the "Rhythmic movement", "Rhythmic space", "Rhythmic pronunciation" diagnostic units are inextricably linked. If skills at the level of the three above-mentioned diagnostic units are developed, then skills at the level of the "Complex rhythm of speech" diagnostic unit will be developing as well.

Taking into account the results of the research, the necessity of changes of purposeful formation of parameters of compositional rhythmic structure of speech with reliance on potential possibilities and their maximum use in the process of speech therapy is outlined.

This prompted us to create the "Complex rhythm of speech" technology, which is based on the formation of movement, rhythm and space as the basic parameters for the further development of speech. "Complex rhythm of speech" technology contains six integrated methods that have already been developed and are being tested to confirm their effectiveness in Kyiv preschool education institutions.

It was the design of integrated approach, which will be interconnected to form the outlined parameters of the compositional rhythmic structure of speech, influencing the mastery of a preschool child, and will improve its condition in preschool children with multiple disabilities and intensify the process of speech activity.

\section{REFERENCES}

Agranovich, Z.E. (2001). Logopedicheskaya rabota po preodoleniyu narushenij slogovoj struktury slov u detej [Speech Therapy Aimed at Overcoming Violations of the Syllable Structure of Words in Children]. Sankt-Peterburg: Detstvo-Press. (In Russian)

Babina, G., Sharipova, N. (2020). Strukturno-slogovaya organizaciya rechi doshkolnikov. Ontogenez i dizontogenez [Structural and Syllabic Organization of Speech in Preschoolers. Ontogenesis and Dysontogenesis]. Moskva: Litres. (In Russian) 
Babych, N., Tychyna, K. (2019). The Influence of Lullabic Songs on the Children's Speech Development. Naukovi zapysky Berdyanskogo derzhavnogo pedagogichnogo universytetu, vol. 1, 11-19, DOI: https://doi.org/10.31494/2412-9208-2019-1-1-11-19.

Benninger, M.S., Zhang, E.S., Chen, B.N., Tierney, W.S., Abdelmalak, B., Bryson, P.C. (2021). Utility of Transnasal Humidified Rapid Insufflation Ventilatory Exchange for Microlaryngeal Surgery. The Laryngoscope, vol. 131(3), 587-591, DOI: https:// doi.org/10.1002/lary.28776.

Bernshtein, N.A. (1947). O postroenii dvizhenij [Construction of Movements]. Moskva: Medgiz. (In Russian)

Bolshakova, S. (2017). Preodolenie narushenij slogovoj struktury slova u detej. Metodicheskoe posobie [Overcoming Violations of the Syllable Structure of the Word in Children. Toolkit]. Moskva: Sfera. (In Russian)

Cherednichenko, N.V. (2016). Osoblyvosti opanuvannya osnov fonetyky ta grafiky molodshymy shkolyaramy iz porushennyamy movlennyevogo rozvytku [Special Features of Mastering the Basics of Phonetics and Graphics in Younger SchoolAge Children with Development Disorders]. Naukovyy chasopys NPU imeni M.P. Dragomanova. Seriya 19: Korekcijna pedagogika ta spetsialna psykholohiya, vol. 32(2), 229-234. (In Ukrainian)

Chetverushkina, N.S. (2016). Slogovaya struktura slova: Sistemnyj metod ustraneniya narushenij [The Syllabic Structure of the Word: A Systematic Method of Eliminating Violations]. Moskva: NKC. (In Russian)

Efimova, O. (2007). Individualnye razlichiya obrazov voobrazheniya u subektov s razlichnoj lateralizaciej sluhorechevyh funkcij [Individual Differences of Imagination Images in Persons with Different Lateralization of Auditory and Speech Functions]. Psihologicheskaya nauka i obrazovanie, vol. 2, 83-92. (In Russian)

Filicheva, T.B., Chirkina, G.V. (1993). Programma obucheniya $i$ vospitaniya detej s fonetiko-fonematicheskim nedorazvitiem [Program for Teaching and Upbringing of Children with Phonetic and Phonemic Underdevelopment]. Moskva: MGOPI. (In Russian)

Freina, L., Ott, M. (2014, Nov. 17-19). Discussing Implementation Choices for Serious Games Supporting Spatial and Orientation Skills. $7^{\text {th }}$ International Conference of Education, Research and Innovation (ICERI), Seville, Spain.

Greenberg, S., Carvey, H., Hitchcock, L., Chang, S.Y. (2003). Temporal Properties of Spontaneous Speech - a Syllable-Centric Perspective. Journal of Phonetics, vol. 31(3-4), 465-485, DOI: https://doi.org/10.1016/j.wocn.2003.09.005.

Levina, R.E. (2005). Narushenie slogovoj struktury u detej [Violation of the Syllabic Structure in Children]. Moskva: ARKTI. (In Russian)

Markova, A. (1961). Osobennosti usvoeniya slogovoj struktury slova u detej, stradayushchih alaliej [Features of Mastering the Syllabic Structure of the Word in Children Suffering from Alalia]. Shkola dlya detej s tyazhelymi narusheniyami rechi, vol. 1, 59-70. (In Russian)

Newcombe, N.S., Frick, A. (2010). Early Education for Spatial Intelligence: Why, What, and How. Mind Brain and Education, vol. 4(3), 102-111, DOI: https://doi. org/10.1111/j.1751-228X.2010.01089. 
Pobrane z czasopisma Annales N - Educatio Nova http://educatio.annales.umcs.pl Data: 26/04/2023 12:37:43

Poeppel, D., Assaneo, M.F. (2020). Speech Rhythms and Their Neural Foundations. Nature Reviews Neuroscience, vol. 21(6), 322-334, DOI: https://doi.org/10.1038/ s41583-020-0304-4.

Shvachkin, N.H. (2004). Vozrastnaya psiholingvistika: Hrestomatiya. Uchebnoe posobie [Age-Related Psycholinguistics: A Reader: Textbook]. Moskva: Labirint. (In Russian). Tierney, A., White-Schwoch, T., MacLean, J., Kraus, N. (2017). Individual Differences in Rhythm Skills: Links with Neural Consistency and Linguistic Ability. Journal of Cognitive Neuroscience, vol. 29(5), 855-868, DOI: https://doi.org/10.1162/ jocn_a_01092.

Tkachenko, T.A. (2004). Korrekciya narushenij slogovoj struktury slova [Correction of Violations of the Syllable Structure of the Word]. Moskva: GNOM I D. (In Russian)

Vizel, T. (2005). Osnovy nejropsihologii: ucheb. dlya studentov vuzov [Basics of Neuropsychology: Textbookfor University Students]. Moskva: ASTAstrel Tranzitkniga. (In Russian) 